\title{
The frequency measurements of dielectric properties in the phase transition range in the $\mathrm{Li}_{0.02} \mathrm{Na}_{0.98} \mathrm{NbO}_{3}$
}

\author{
W.Śmiga \\ Institute of Physics and Computer Science, Pedagogical University, \\ 2 Podchorążych Str., 30-084 Kraków, Poland
}

Received September 1, 1998

Measurement of the temperature, time and frequency changes of dielectric permittivity and dielectric loss in polycrystalline $\mathrm{Li}_{0.02} \mathrm{Na}_{0.98} \mathrm{NbO}_{3}$ have been carried out. The dielectric permittivity $\varepsilon$ has been measured in the temperature range $300 \mathrm{~K}<T<750 \mathrm{~K}$. The results obtained point out to the existence of polar microregions above $T_{\mathrm{c}}$ and a complicated domain structure below $T_{\mathrm{c}}$.

Key words: dielectric permittivity, dielectric loss, ferroelectric

PACS: 77.22.-d, 77.22.Ch, 77.84.Dy

\section{Introduction}

The developing progress of the present-day technique spurs the need of permanent research of newer and newer materials as well as the elaboration of their obtaining. The compounds of $\mathrm{ABO}_{3}$-type with perovskite structure are one of the most interesting classes of materials. And among them the niobates are of great interest from the point of view of fundamental research as well as regarding their applications. The sodium niobate is the best known of all niobates [1,2], which is an antiferroelectric with very interesting dielectric and semiconducting properties $[3,4]$. The properties of ferro- and antiferroelectric solid solutions of lithium niobate in sodium niobate $\mathrm{Li}_{x} \mathrm{Na}_{1-x} \mathrm{NbO}_{3}[5,6]$ are also very interesting.

The $\mathrm{NaNbO}_{3}$ samples show the following transitions: orthorombic-543K-tetragonal-653K-cubic. Krajnik [7] investigated the phase transition of $\mathrm{NaNbO}_{3}: \mathrm{LiNbO}_{3}$-system by determining the dielectric permittivity in different fields and at different temperatures. He reported that ferroelectric pseudotetragonal and orthorombic phases emerged, when $\mathrm{LiNbO}_{3}$ content increased.

The aim of the present paper was to investigate the effect of the electric field frequency on the temperature and time changes of dielectric permittivity $\varepsilon$ and dielectric loss $\tan \delta$. 


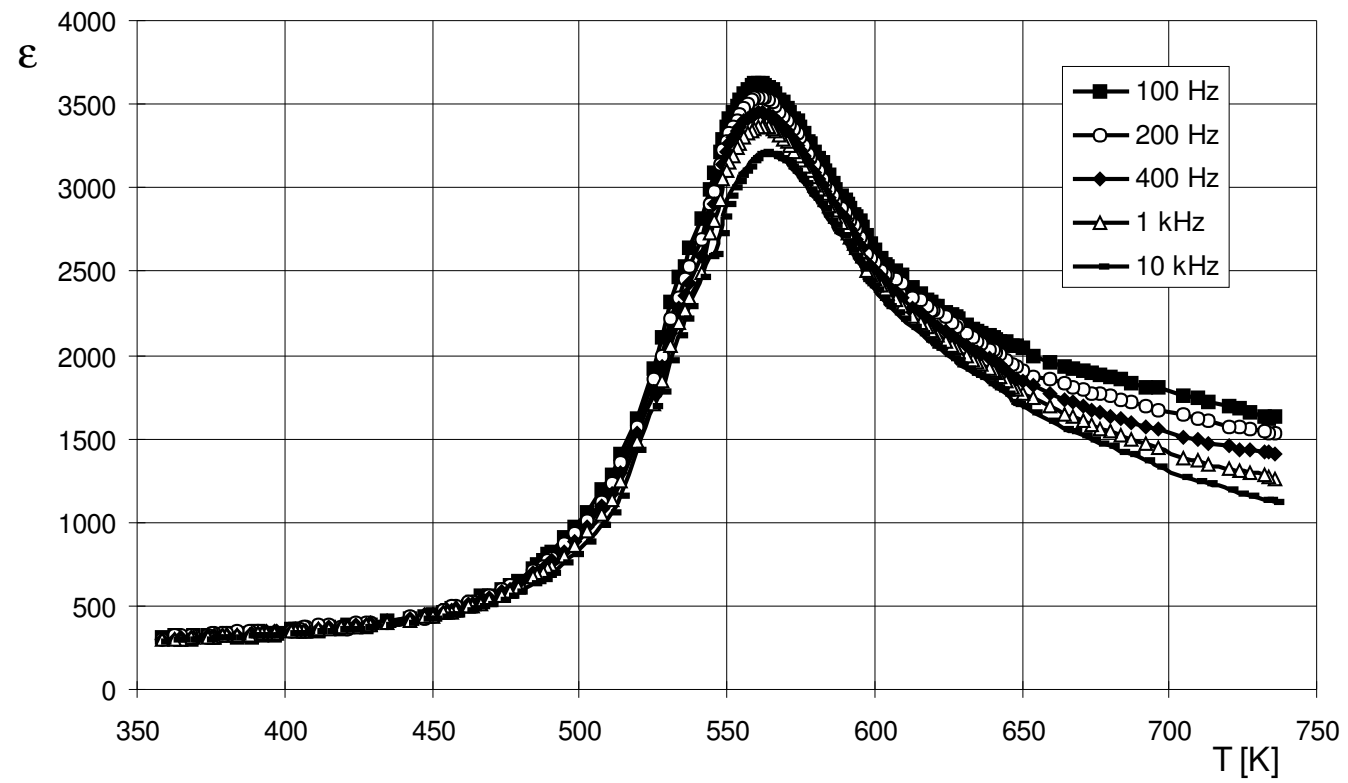

Figure 1. Temperature changes of dielectric permittivity for $\mathrm{Li}_{0.02} \mathrm{Na}_{0.98} \mathrm{NbO}_{3}$ at cooling.

\section{Experiment}

The temperature, frequency and time measurements of electric permittivity were made by means of a computerized system based on BM 595 RLCG-meter at measuring electric field level $400 \mathrm{~V} / \mathrm{m}$. The measurements were performed in the temperature range $300 \mathrm{~K}-750 \mathrm{~K}$ and in the frequency range $100 \mathrm{~Hz}-20 \mathrm{kHz}$ at a controlled rate $4 \mathrm{~K} / \mathrm{min}$ on cooling. For time dependent measurements, the sample was being annealed in the temperature of $800 \mathrm{~K}$ during 1 hour in order to eliminate the internal and near-electrode stress. The temperature of the sample was stabilized with an accuracy of $\pm 0.2 \mathrm{~K}$. The sample used in the experiment had the shape of a disk with the surface equal to $48 \mathrm{~mm}^{2}$ and the thickness equal to $2.38 \mathrm{~mm}$. The $\mathrm{Li}_{0.02} \mathrm{Na}_{0.98} \mathrm{NbO}_{3}$ polycrystal has been obtained by synthesis of $\mathrm{Na}_{2} \mathrm{CO}_{3}, \mathrm{Nb}_{2} \mathrm{O}_{5}$ and $\mathrm{Li}_{2} \mathrm{CO}_{3}[6]$. The sample was prepared in the Institute of Solid State Physics at the University of Latvia in Riga.

\section{Results}

Temperature changes of dielectric permittivity $\varepsilon$ and dielectric loss $\tan \delta$ of the polycrystal on cooling for different frequencies of the measuring field are presented in figures 1 and 2. The maximum of dielectric permittivity is observed on cooling at about $560 \mathrm{~K}$.

It can be noticed, that the maximum value of dielectric permittivity $\varepsilon$ decreases with the increase of the frequency of measuring field. On the other hand, the temperature, at which it occurs, increases with the increase of frequency. Thermal hysteresis between heating and cooling cycles is equal to $16 \mathrm{~K}$. 


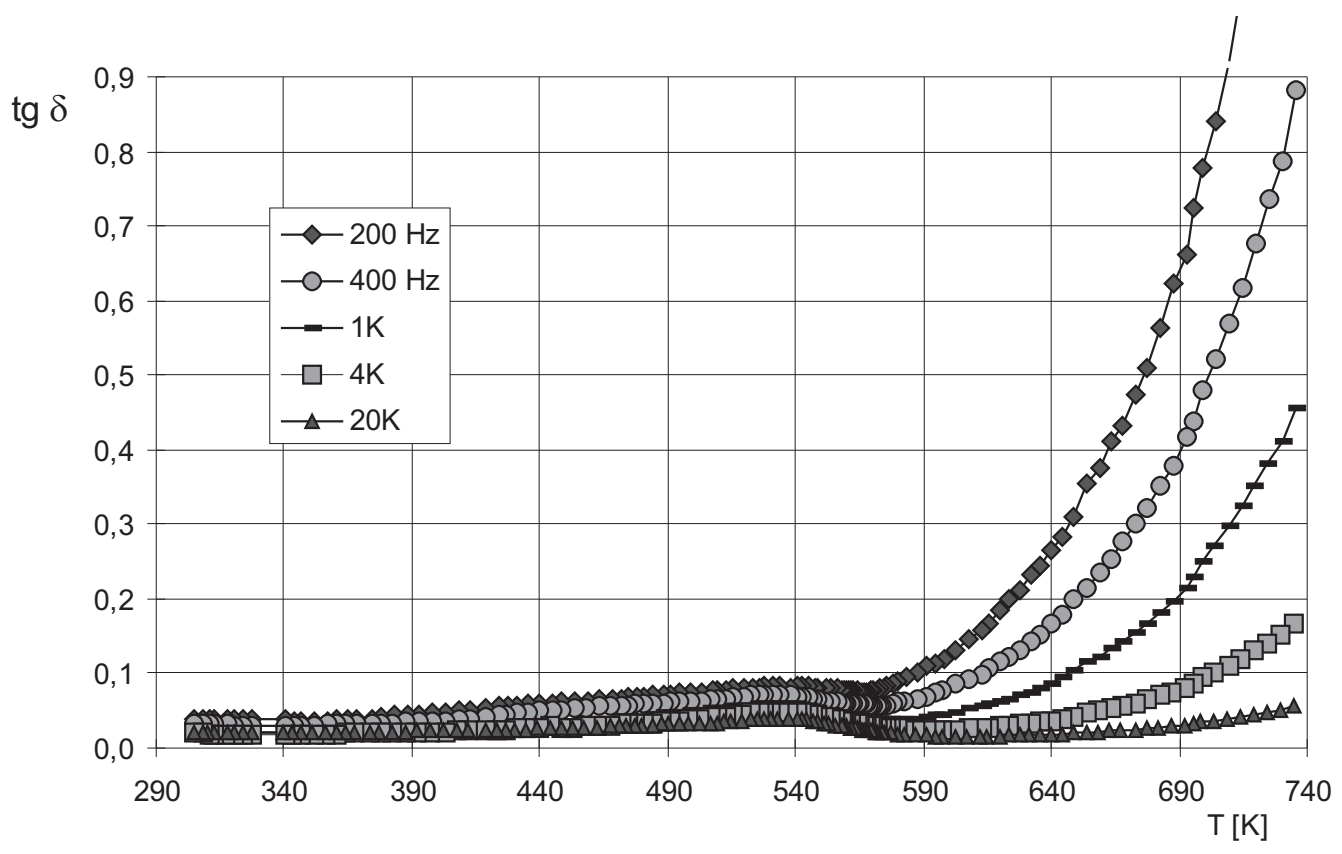

Figure 2. Temperature changes of dielectric losses for $\mathrm{Li}_{0.02} \mathrm{Na}_{0.98} \mathrm{NbO}_{3}$ at cooling.

Analysing the temperature dependence of $\tan \delta$ we can notice the anomaly close to the temperature of $540 \mathrm{~K}$ (this anomaly is well seen especially for low frequencies). In the whole range of the investigated temperatures the value of $\tan \delta$ decreases with the increase of frequency.

The time changes of dielectric permittivity and dielectric loss for $\mathrm{Li}_{0.02} \mathrm{Na}_{0.98} \mathrm{NbO}_{3}$ for several temperatures (below and above phase transition) and frequencies are shown in figures 3 and 4 . Strong time dependence of dielectric permittivity in temperature region of $500-580 \mathrm{~K}$ was observed. The time changes of $\varepsilon$ (as a dependence $\varepsilon / \varepsilon_{(t=0)}$ on $t$ ) are presented in figure 3 . These changes depend both on temperature and frequency. In the range of phase transition the time changes $\varepsilon(t)$ are the largest. Time changes of dielectric loss $\tan \delta$ (as a dependence $\tan \delta / \tan \delta_{(t=0)}$ on $t$ ) are presented in figure 4 . For $\tan \delta$ the time changes increase with the increase of frequency and their values also depend on temperature.

The investigations carried out show that the dielectric permittivity $\varepsilon$ and $\tan \delta$ change in time according to the logarithmic law [8].

\section{Summary}

Based on the investigations performed the following conclusions can be drawn:

- the substitution of sodium ions by lithium ions leads to the arising of polar regions above $T_{\mathrm{c}}[9]$,

- the time changes of dielectric permittivity $\varepsilon$ below $T_{\mathrm{c}}$ can be connected with the changes of domain structure $[8,10]$, tending to achieve the stable state, 

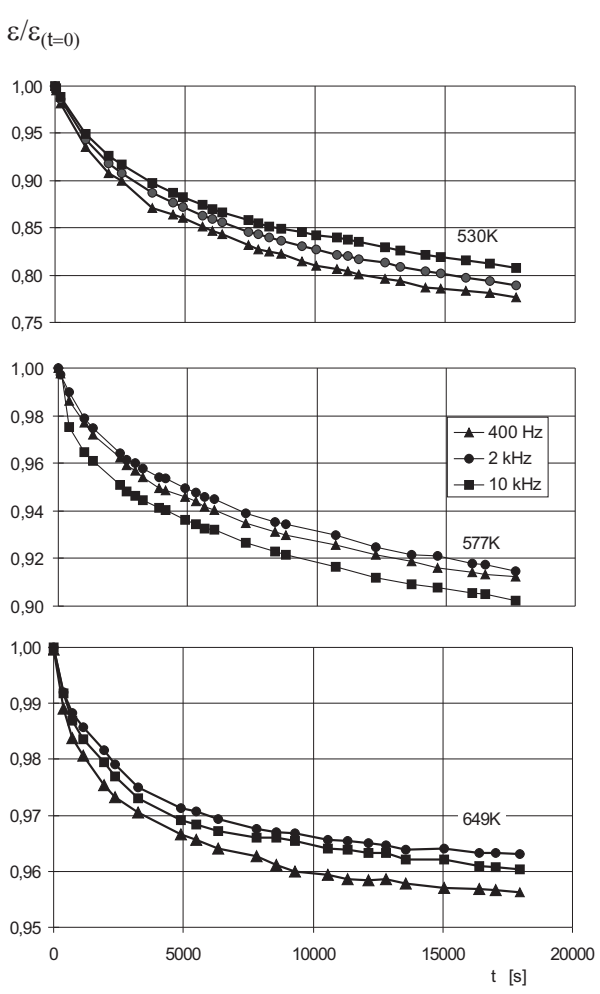

Figure 3. Time changes of dielectric permittivity for $\mathrm{Li}_{0.02} \mathrm{Na}_{0.98} \mathrm{NbO}_{3}$.
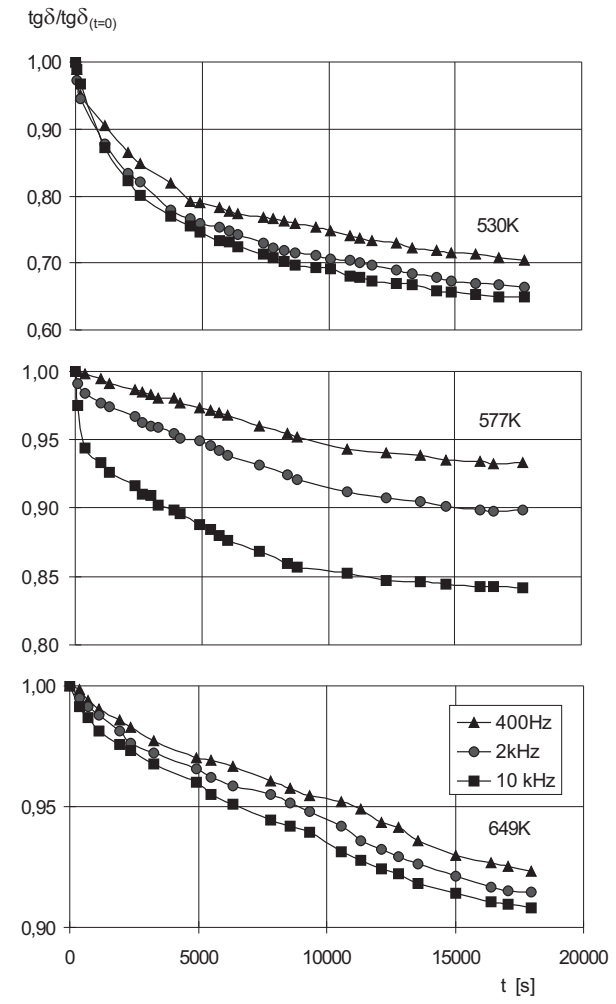

Figure 4. Time changes of dielectric losses for $\mathrm{Li}_{0.02} \mathrm{Na}_{0.98} \mathrm{NbO}_{3}$.

characterized by the smallest value of free energy, in the material,

- the defects of the lattice and the impurities strongly effect the $\varepsilon$ value and its changes versus the temperature and versus the frequency of the applied electric field.

Taking into account the latter conclusion the following explanation can be proposed. While annealing the ceramic and depositing electrodes some defects arise. After cooling some of them are frozen. The most active point defects, which are oxygen vacancies, play the basic role in solid solution $\mathrm{Li}_{x} \mathrm{Na}_{1-x} \mathrm{NbO}_{3}$ and in $\mathrm{NaNbO}_{3}$. These defects, frozen in cooling process, become the centres of capture for the electron emitted from the metallic electrodes to the inside of the sample. These centres, which are being polarized under the effect of the alternating field, give rise to polar microregions. They contribute to the entire polarization of the sample and cause the increase of dielectric permittivity value in the cooling process. The interaction of these microregions leads to the emerging of time dependent dielectric permittivity as well as to its dependence on the frequency of the measuring field. 


\section{References}

1. Megaw H.D. The seven phases of sodium niobate. // Ferroelectrics, 1974, vol. 7, p. 87.

2. Kuś C., Ba̧k W., Ptak W. S., Śmiga W. Antiferroelectric-paraelectric phase transformation in nonstoichiometric $\mathrm{NaNbO}_{3}$. // Ferroelectrics, 1988, vol. 81, p. 277.

3. Sadel A., von der Mühll R., Ravez J., Chaminade I.P., Hagenmuller P. Synthese et etude des transitions de phases de ceramiques et de cristaux de composition $\mathrm{Li}_{0.02} \mathrm{Na}_{0.98} \mathrm{NbO}_{3}$. // Solid State Commun., 1982, vol. 345, p. 44.

4. Kuś C., Ptak W.S., Śmiga W., Rajewski I.P. Dielektriczeskie i poluprowodnikowyje swojstwa twerdogo rastwora $\mathrm{Na}_{1-x} \mathrm{Li}_{x} \mathrm{NbO}_{3}$ dla $0<x<0.2$. // Izv. Akad. Nauk SSSR, 1991, vol. 55, p. 564 (In Russian).

5. Kuś Cz., Śmiga W., Garbarz B. Zmiany temperaturowe i czasowe przenikalności elektrycznej w polikrysztale $\mathrm{Li}_{0.04} \mathrm{Na}_{0.96} \mathrm{NbO}_{3}$. // Technologia Elektronowa, 1997, p. 222 (In Polish).

6. Kuś Cz., Dambakalne M.J., Brante I.V, Bormanis K., Plaude A.V. Production and properties of ferroelectrics materials based on $\mathrm{NaNbO}_{3}$ and solid solutions $\mathrm{Na}_{1-x} \mathrm{Li}_{x} \mathrm{NbO}_{3}$. // Ferroelectrics, 1988, vol. 81, p. 281.

7. Krajnik N.N. Antisegneto i segnetoelektriczeskije swojstwa nekotorych twerdych rastworow na osnowie niobata natria. // Izw. Akad. Nauk SSSR, Ser. Fiz., 1958, vol. 22, No. 12, p. 1492.

8. Kuś C., Jankowska I., Śmiga W., Rajfur Z. The changes of dielectric constant for polycrystalline samples of $\mathrm{Li}_{x} \mathrm{Na}_{1-x} \mathrm{NbO}_{3}$. // Ferroelektrizität, 1991, vol. 90, p. 133.

9. Śmiga W., Konieczny K., Kuś Cz., Burzyńska M. Dielectric properties of $\mathrm{Li}_{0.003} \mathrm{Na}_{0.997} \mathrm{NbO}_{3}$ ceramics. // Ferroelectrics, 1998 (in press).

10. Sadel A., von der Mühll R., Ravez J. Etude optique et couplage ferroelectriqueferroelastique de cristaux de composition $\mathrm{Li}_{0.02} \mathrm{Na}_{0.98} \mathrm{NbO}_{3}$. // Mat. Res. Bull., 1983, vol. 18, p. 45 (in French). 


\section{Частотні вимірювання діелектричних властивостей} $\mathrm{Li}_{0.02} \mathrm{Na}_{0.98} \mathrm{NbO}_{3}$ в області фазового переходу

\section{В.Сьміга}

Інститут фізики та обчислювальної техніки, Педагогічний університет,

Польща, 30-084 Краків, вул. Подхоронжих, 1

Отримано 1 вересня 1998 р.

Проведено вимірювання температурних, часових і частотних залежностей діелектричної проникності і діелектричних втрат у полікристалічному $\mathrm{Li}_{0.02} \mathrm{Na}_{0.98} \mathrm{NbO}_{3}$ в області температур $300 \mathrm{~K}<T<750 \mathrm{~K}$. Отримані результати вказують на існування полярних мікроскопічних областей вище $T_{\mathrm{c}}$ та складної доменної структури нижче $T_{\mathrm{c}}$.

Ключові слова: діелектрична проникність, діелектричні втрати, сегнетоелектрик

PACS: 77.22. $-d$, 77.22.Ch, 77.84.Dy 